THE influence of anti-allergic drugs, epinastine hydrochloride (EP) and disodium cromoglycate (DSCG), on the co-stimulatory molecule expression was examin ed using in vitro cell culture technique. Spleen cells obtained from BALB/c mice 10 days after immunization with haemocyanin absorbed to aluminium hydroxide were cultured in the presence of $\mathbf{1 0 0 . 0}$ $\mu \mathrm{g} / \mathrm{ml}$ haemocyanin and various concentrations of the agents. Low concentrations $\left(<1.5 \times 10^{-4} \mathrm{M}\right)$ of EP and DSCG did not influence spleen cell blastic activity induced by antigenic stimulation, whereas these agents caused significant inhibition of spleen cell activation when $2 \times 10^{-4} \mathrm{M}$ of the agents were added to cell cultures. EP and DSCG also did not affect blastic activity of sensitized splenic $T$ cells by anti-CD3 monoclonal antibody stimulation even when these cells were cultured in the presence of $2 \times 10^{-4} \mathrm{M}$ of the agents. We next examined the influence of EP and DSCG on the expression of co-stimulatory molecules on spleen cells in response to antigenic stimulation. Sensitized spleen cells were cultured in the presence of $2 \times 10^{-4} \mathrm{M}$ of the agents and the expression of molecules were examined by flow cytometer $24 \mathrm{~h}$ later. EP and DSCG suppressed the expression of costimulatory molecules, CD40 and CD80, but not CD86, on splenic $B$ cells which were enhanced by antigenic stimulation in vitro.

Key words: Anti-allergic agent, Co-stimulatory molecule, Expression, Inhibition, Mouse, Spleen cell

\section{Suppressive effects of co-stimulatory molecule expressions on mouse splenocytes by anti-allergic agents in vitro}

\author{
Jun-ichi Ito ${ }^{1}$, Kazuhito Asano ${ }^{2, C A}$, Elzbieta Tryka ${ }^{1, *}$, \\ Ken-ichi Kanai ${ }^{1}$, Sumiko Yamamoto ${ }^{1}$, \\ Tadashi Hisamitsu ${ }^{2}$ and Harumi Suzaki ${ }^{1}$
}

${ }^{1}$ Department of Otolaryngology, and ${ }^{2}$ Department of Physiology, School of Medicine, Showa University, Tokyo, Japan

\footnotetext{
${ }^{\mathrm{CA}}$ Corresponding Author, Department of Physiology, School of Medicine, Showa University, 1-5-8 Hatanodai, Shinagawa-ku, Tokyo 142-8555, Japan Tel: +81-3-3784-8110 Fax: +81-3-3784-5368 E-mail: asakazu@med.showa-u.ac.jp

* Present Address: Department of Otolaryngology, Medical Acade my, ul. Jaczew skiego 8, 20-090 Lublin, Poland
}

\section{Introduction}

Current theories on the pathogenesis of allergic diseases such as asthma, atopic dermatitis and allergic rhinitis, clearly show that inflammatory responses are important determinants of the diseases. ${ }^{1}$ Several inflammatory cells including eosinophils and mast cells, and $\operatorname{IgE}$ antibody have been postulated to participate in the inflammatory responses to antigenic stimulation. ${ }^{2,3}$ It is generally accepted that the central cells in these responses are the Tlymphocytes: $\mathrm{T}$ lymphocytes, especially helper $\mathrm{T}$ lymphocytes, upon contact with allergens, activate and release several types of lymphokines that control the establishment and regulation of the inflammatory responses that underly many allergic diseases.

Antige n-specific $T$ cell activation requires triggering via the antigen-specific $T$ cell receptor and a costimulatory signal usually provided by antigen presenting cells (APC) including $B$ cells and macrophages. ${ }^{4-7}$ Interaction of $\mathrm{T}$ cells with antigen in the absence of sufficient co-stimulation can result in T cell unresponsiveness-termed anergy. ${ }^{7,8}$ A number of APC surface determinants have been shown to be capable of providing $\mathrm{T}$ cell co-stimulation. Activated APC express $\mathrm{CD} 80$, which co-stimulates $\mathrm{T}$ cells via binding to the counter receptor $\mathrm{CD} 28 .^{4,7} \mathrm{CD} 86$, which also binds to $\mathrm{CD} 28$, is constitutively expressed on professional and non-professional APC earlier than CD80. ${ }^{4,7}$ The interaction between CD 40 molecules and its ligand, CD40L, on $\mathrm{T}$ cells has also been identified as an important co-stimulatory signal required for switch recombination to $\operatorname{IgE}$ synthesis..$^{9,10}$

A number of anti-allergic drugs such as azelastine, epinastine hydrochloride (EP), and disodium cromoglycate (DSCG) have been developed and are used clinically in the treatment and the management of allergic diseases. The mechanisms of action of these agents on allergic diseases are generally believed to be owing, in part, to their inhibitory action on chemical mediator release from effector cells such as eosinophils and mast cells. ${ }^{11,12}$ Although these agents are also reported to display antagonistic effects on chemical mediators, ${ }^{13,14}$ there is little information about the influence of anti-allergic agents on co-stimulatory molecule expression. Therefore, in this study we examined whether anti-alle rgic agents could modulate the ex pression of co-stimulatory molecules on lymphocytes by an in vitro cell culture technique. 


\section{Materials and methods}

\section{Mice}

Specific pathogen free, male BALB/c mice, 5 weeks of age were purchased from Charles River Japan Inc. (Atsugi, Japan). Each ex perimental and control group consisted of five mice. Animal care and handling were in accordance with the principles stated in the Guide for the Care and Use of Laboratory Animals (Prime Minister's Office of Japan, Publication No. 85-23, 1985). The experimental protocols of this study were approved by the Animal Care and Use Committee of Show a University.

\section{Immunization}

Mice were immunized by intraperitoneal injection of $8.0 \mu \mathrm{g} / \mathrm{ml}$ haemocyanin (Sigma Chemical Co., St Louis, MO) absorbed to $4.0 \mathrm{mg}$ aluminium hydroxide (Wako Chemical Co., Ltd, Osaka, Japan) in $0.5 \mathrm{ml}$ saline.

\section{Agents}

EP was kindly supplied by Boehringer Ingelhaim (Ingelhaim, Germany) as a water soluble pure powder. The powder was dissolved in saline at a concentration of $5 \times 10^{-2} \mathrm{M}$. This solution was then filtered through a $0.22 \mu \mathrm{m}$ filter (Nihon Millipore Co., Ltd, Yonezaw a, Japan) and stored as a stock solution at $4^{\circ} \mathrm{C}$ until used. All dilutions used in this study were prepared from this stock solution by dilution with RPMI-1640 medium (Wako Chemical) supplemented with $10 \%$ foetal calf serum (Sigma chemical; RPMIFCS). DSCG was purchased from Fujisawa-Fison Co., Osaka, Japan as a solution in distilled water. This solution contained 5.0 M DSCG. All dilutions used in this study were prepared from this solution.

\section{Cell preparation}

Spleen was removed from five individual mice 10 days after the immunization. These organs were pressed through 60 gauge steel sieves into saline. The cells were washed once with saline and then treated with Tris-buffered ammonium chloride $(17 \mathrm{mM}$ Tris- $\mathrm{HCl}-$ $0.73 \% \mathrm{NH}_{4} \mathrm{Cl}, \mathrm{pH} 7.6$ ) for $5 \mathrm{~min}$ to lyse red blood cells. After passing through 200 gauge steel sieves, the residual cells were washed three times, resuspended in saline at a concentration of $1 \times 10^{6}$ cells $/ \mathrm{ml}$ and used for splenocytes. In the case of experiments using purified $\mathrm{T}$ cells, $\mathrm{T}$ cells were separated from splenocytes using a magnetic cell separator (Milteny Biotec $\mathrm{GmbH}$, Bergisch Gladbach, Germany) according to the manufacturer's instructions. Splenocytes were labeled with anti-mouse CD19 monoclonal antibody $(\mathrm{mAb})$-coated magnetic microbeads (Milteny Biotec $\mathrm{GmbH}$ ). These cells were then applied to the column placed in the separator and the column was washed with PBS. The entire effluated cells were washed tw ice and resuspended in saline at a concentration of $1 \times 10^{6}$ cells $/ \mathrm{ml}$. The purity of the cells was checked by incubating separated cells with fluorescein isothiocyanate (FITC)-conjugated $\mathrm{mAb}$ to CD90 (PharMingen, San Diego, CA). Fluorescence microscopic examination revealed that more than $98 \%$ of the cells were CD90 positive, and these cells were used as splenic $\mathrm{T}$ cells.

\section{Cell proliferation assay}

Splenocytes prepared as above were washed once and resuspended in RPMI-1640 medium (Wako Chemical) supplemented with $10 \%$ foetal calf serum (Sigma Chemical; RPMI-FCS) at a concentration of $1 \times 10^{6}$ cells $/ \mathrm{ml}$. To examine blastic activity of the cells, $100 \mu \mathrm{l}$ of cell suspension was introduced into each well of 96-well flat-bottomed culture plates (Nunc, Denmark). Various concentrations of the anti-allergic agents, EP and DSCG, and $100.0 \mu \mathrm{g} / \mathrm{ml}$ haemocyanin were added in another $100 \mu \mathrm{l}$ to give a total volume of $200 \mu \mathrm{l}$. These mixtures were then incubated at $37^{\circ} \mathrm{C}$ in a humidified atmosphere of $5 \% \mathrm{CO}_{2}$ in air. After $40 \mathrm{~h}$ culture, $37 \mathrm{kBr}$ of ${ }^{3} \mathrm{H}$-thymidine (specific activity $740 \mathrm{GBq} / \mathrm{mmol}$, New England Nuclear, Boston, MA, USA) was added to each well, and the plate was maintained for another $8 \mathrm{~h}$. Cells were collected on glass fiber filters for liquid scintillation counting using a Packard Tricarb liquid scintillation spectorometer. The results were expressed as mean counts per minute $(\mathrm{cpm}) \pm S D$ of triplicate cultures. For examination of the proliferative response of splenocytes to anti-CD3 stimulation, $100 \mu \mathrm{l}$ of PBS containing $20.0 \mu \mathrm{g} / \mathrm{ml}$ of $\mathrm{mAb}$ to mouse CD3E (Genzyme, Minneapolis, MN, USA) was introduced into each well of 96-w ell flat-bottomed culture plates (Nunc, Denmark) in triplicate and incubated overnight at $4^{\circ} \mathrm{C} .{ }^{15} \mathrm{Be}$ fore use, the plates were washed once with $200 \mu$ PBS. Splenic $T$ cells prepared as above were cultured in $\mathrm{mAb}$-coated plates that contained various concentrations of agents at $2 \times 10^{5}$ cells in a final volume of $200 \mu \mathrm{l}$ for $48 \mathrm{~h}$. The cell proliferation was assessed in a similar manner. For examination of the influence of the agents on co-stimulatory molecule expressions, $0.5 \mathrm{ml}$ of the cell suspensions $\left(5 \times 10^{5}\right.$ cells $)$ were dispensed into 24-well flat-bottomed culture plates (NUNC) that contained $0.5 \mathrm{ml}$ of various concentrations of the agents and $100.0 \mu \mathrm{g} / \mathrm{ml}$ antigen. The plates were maintained for $24 \mathrm{~h}$ at $37^{\circ} \mathrm{C}$ in a humidified atmosphere of $5 \% \mathrm{CO}_{2}$ in air. The cells were then collected by centrifugation, washed twice with saline, resuspended at a concentration of $1 \times 10^{5}$ cells $/ \mathrm{ml}$, and stored on ice until processed.

\section{Flow cytometry}

The mAbs used for flow cytometry were anti-mouse $\mathrm{CD} 16 / 32 \mathrm{mAb}$, FITC-conjugated anti-mouse CD40, $\mathrm{CD} 80$ and CD86 mAbs. They were purchased from 

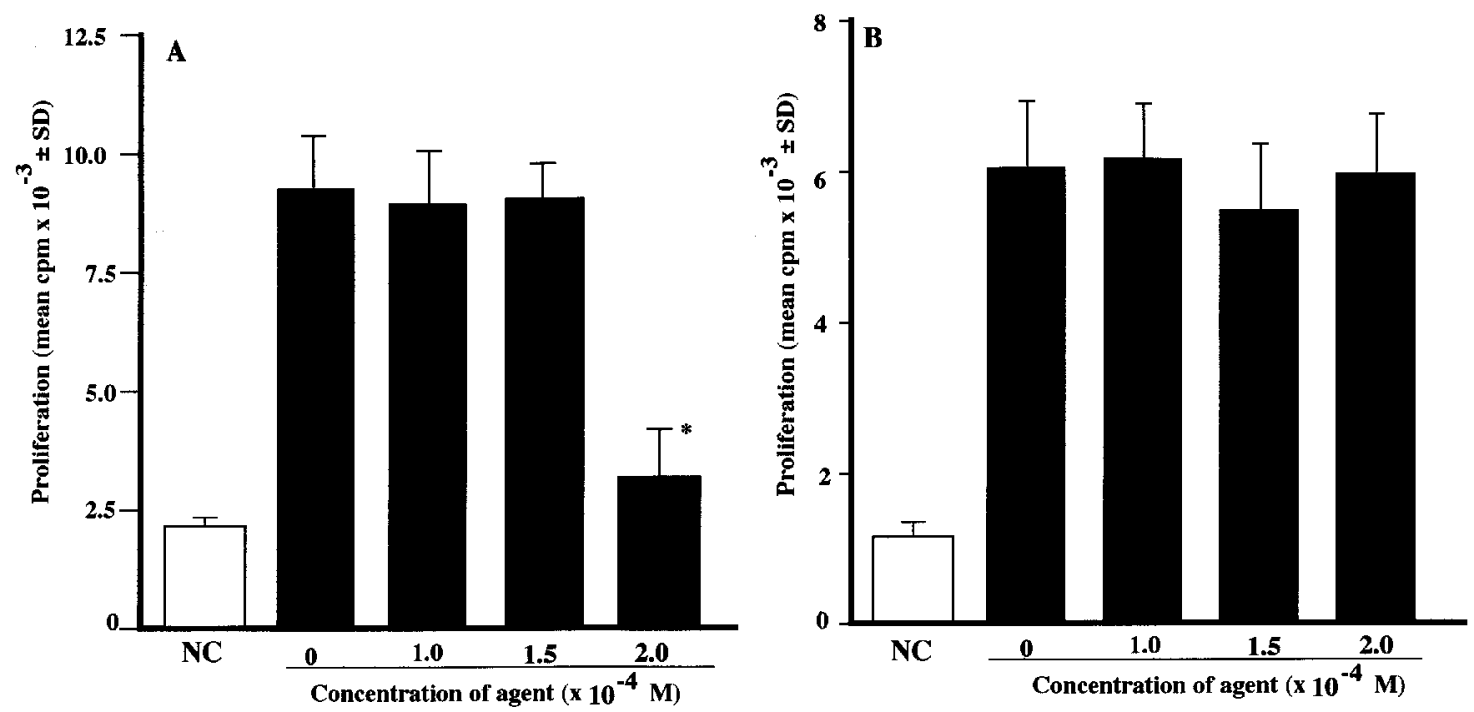

FIG. 1. Influence of epinastine hydrochloride (EP) on in vitro proliferative response of splenic lymphocytes. BALB/c mice were immunized by intraperitoneal injection with $8.0 \mu \mathrm{g}$ haemocyanin absorbed to $4.0 \mathrm{mg}$ aluminium hydroxide in a volume of $0.5 \mathrm{ml}$. Spleen cells $\left(1 \times 10^{5}\right.$ cells $\left./ 0.1 \mathrm{ml}\right)$ prepared from mice 10 days later were cultured in the presence of various concentrations of EP for $48 \mathrm{~h}$, which were stimulated with specific antigen (A). Splenic T cells $\left(2 \times 10^{5}\right.$ cells $\left./ 0.1 \mathrm{ml}\right)$ were also cultured with immobilized anti-CD3 $\varepsilon$ monoclonal antibody in the presence of various concentrations of EP for $48 \mathrm{~h}$ (B). These cells were pulsed with $1.0 \mu \mathrm{Ci}^{3} \mathrm{H}$-thymidine for the last $8 \mathrm{~h}$ of culture. The results were expressed as the mean $\pm S D$ of five individual mice. NC: non-stimulated control. ${ }^{*} P<0.01$, significantly different as compared with no agent.

PharMingen. Before staining CD40, CD80 and CD86 molecules with specific antibodies, the purified cultured $\mathrm{B}$ cells $\left(1 \times 10^{6}\right.$ cells $)$ were treated with $1.0 \mu \mathrm{g}$ of anti-mouse $\mathrm{CD} 16 / 32 \mathrm{mAb}$ for $5 \mathrm{~min}$ at $4^{\circ} \mathrm{C}$ to block non-specific $\mathrm{Fc}$ receptor mediated binding of antibodies. Pre-treated cells were then stained with either FITC-conjugated $\mathrm{mAb}$ to CD40, CD80 or CD86 for $25 \mathrm{~min}$ at $25^{\circ} \mathrm{C}$. After washing once, cells were suspended in saline, and assayed for fluorescence intensity on cells using Flow cytometer (Becton Dickinson, Mountain View, CA, USA).

\section{Statistical analysis}

The statistical significance of the difference in the mean value between two groups was examined by the Mann-Whitney $U$ test.

\section{Results}

\section{Influence of EP on proliferative response of lymphocytes in vitro}

The first set of experiments was designed to examine the influence of EP on proliferative response of spleen cells induced by in vitro stimulation with antigens. Spleen cells prepared from five individual mice immunized with haemocyanin were cultured in vitro in the presence of $100.0 \mu \mathrm{g} / \mathrm{ml}$ haemocyanin and various concentrations of EP for $48 \mathrm{~h}$. As show $\mathrm{n}$ in Fig. 1A, low doses of EP $\left(10^{-4} \mathrm{M}\right.$ and $\left.1.5 \times 10^{-4} \mathrm{M}\right)$ did not affect the proliferative activities of spleen cells in response to haemocyanin stimulation in vitro. How- ever, a statistically significant inhibition of cell proliferation was observed when the cells were cultured in the presence of $2 \times 10^{-4} \mathrm{M}$ of the agent. Further experiments were carried out to examine whether the suppressive activity of EP on antigen-induced cell proliferation was also observed in cells stimulated by anti-CD3 mAb. To do this, splenic $\mathrm{T}$ cells from haemocyanin-immunized mice were cultured with solid phase of $\mathrm{mAb}$ in the presence of various doses of EP for $48 \mathrm{~h}$. As shown in Fig. 1B, EP did not interfere with the proliferative response of sensitized splenic $T$ cells even when the cells were cultured with $2 \times$ $10^{-4} \mathrm{M} \mathrm{EP}$.

\section{Influence of EP on co-stimulatory molecule expression}

This study was carried out to examine the influence of EP on co-stimulatory molecule expressions on splenocytes. Spleen cells prepared from haemocyanin-immunized mice were cultured in vitro in the presence of $100.0 \mu \mathrm{g} / \mathrm{ml}$ hae mocyanin and $2 \times 10^{-4} \mathrm{M}$ of EP for $24 \mathrm{~h}$. The cultured cells were stained with FITC-labeled $\mathrm{mAbs}$ against co-stimulatory molecules and were analyzed by flow cytometry for the expression of CD40, CD80 and CD86 on the ir cell surface. As show $\mathrm{n}$ in Fig. 2, addition of EP into cell cultures at a dose of $2 \times 10^{-4} \mathrm{M}$ significantly suppressed CD40 expression on the cells, which were enhanced by in vitro stimulation with haemocyanin. EP also suppresses the ability of the cells to express CD80 molecules on their cell surface induced by antigenic stimulation in vitro (Fig. 2). 

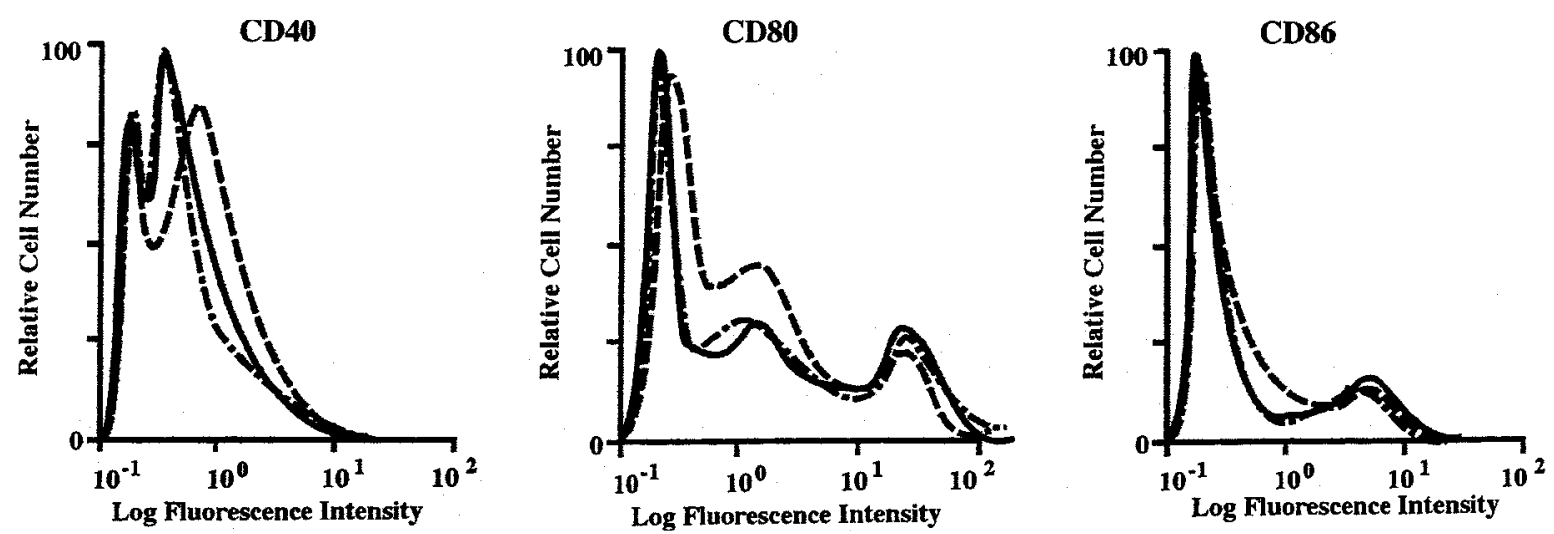

FIG. 2. Influence of epinastine hydrochloride (EP) on co-stimulatory molecule expression on spleen cells induced by antigenic stimulation. Spleen cells $\left(1 \times 10^{6}\right.$ cells $\left./ \mathrm{ml}\right)$ prepared from five individual mice 10 days after immunization were cultured with or without $2 \times 10^{-4} \mathrm{M}$ EP for $24 \mathrm{~h}$. The expression was analyzed by flow cytometer: $(-)$ cultured without antigen; $(----)$ cultured with antigen; $(-\cdot-\cdot-)$ cultured with antigen and EP.

Influence of DSCG on the response of splenocytes to antigenic stimulation

Since many kinds of anti-allergic agents are used clinically, the results described above leave open the questions of whether these anti-allergic agents have similar suppressive effects on cell functions to those observed in EP. Therefore, we chose DSCG, one of the best-known anti-allergic agents, and examined whether it also has inhibitory effects on cell functions, such as proliferation and co-stimulatory molecule expression, induced by in vitro antigenic stimulation. As in the case of EP, DSCG exerted suppressive effects on antigen-induced, but not antiCD3-mediated, proliferative responses of splenocytes
(Fig. 3A and B), when the cells were cultured in the presence of $2 \times 10^{-4} \mathrm{M}$ DSCG. Flow cytometric analysis also revealed the suppressive activity of DSCG on the expression of co-stimulatory molecules, CD40 and CD80, which are enhanced by antigenic stimulation in vitro (Fig. 4)

\section{Discussion}

Asthma and atopic allergy are characterized by infiltration of the bronchial and nasal mucosa with large numbers of activated eosinophils and mast cells and the presence of elevated concentrations of chemical mediators as well as granule-derived basic proteins. ${ }^{2,3}$ The acute symptoms of allergy and asthma
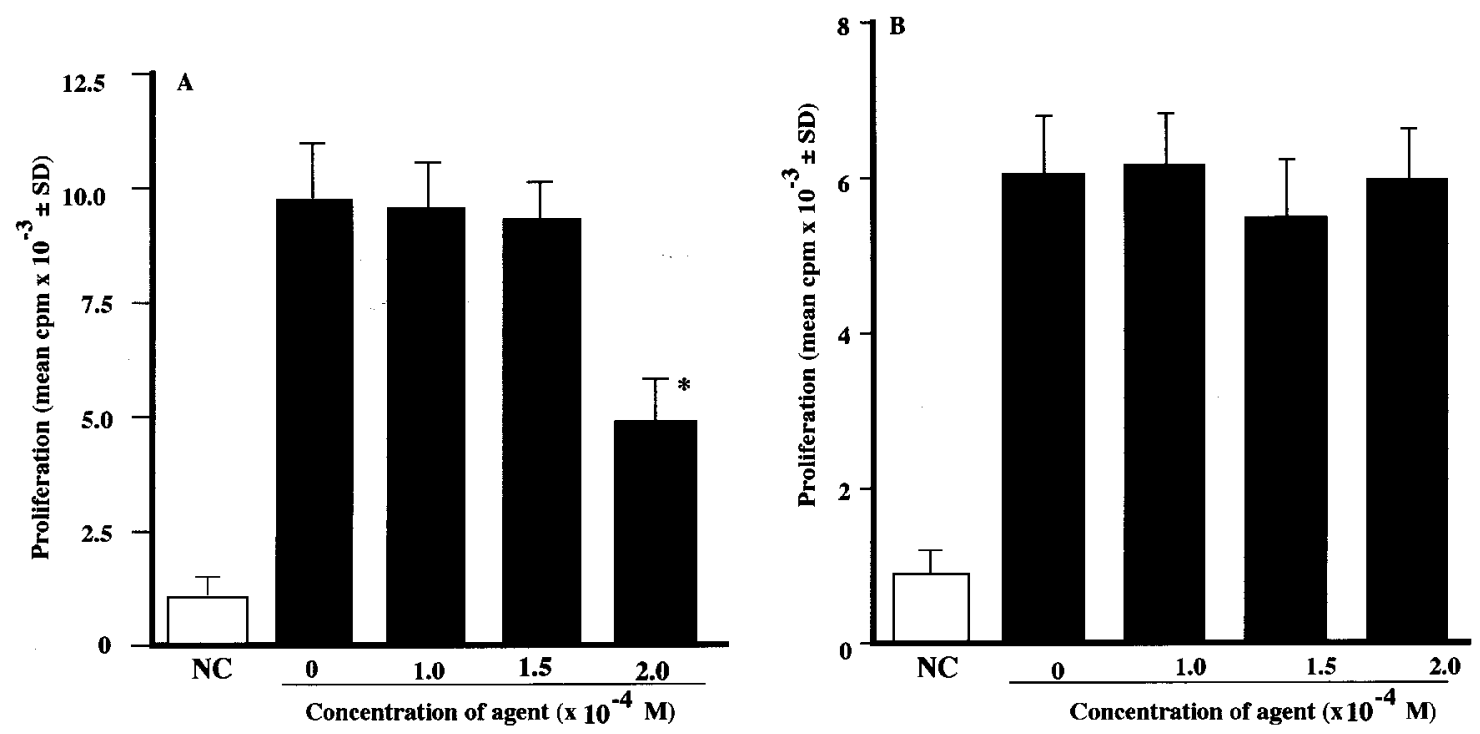

FIG. 3. Influence of disodium cromoglycate (DSCG) on proliferative response of lymphocytes in vitro. BALB/c mice were immunized by intraperitoneal injection with $8.0 \mu \mathrm{g}$ haemocyanin absorbed to $4.0 \mathrm{mg}$ aluminium hydroxide in a volume of $0.5 \mathrm{ml}$. Spleen cells $\left(1 \times 10^{5}\right.$ cells $\left./ 0.1 \mathrm{ml}\right)$ prepared from mice 10 days later were cultured in the presence of various concentrations of DSCG for $48 \mathrm{~h}$, which were stimulated with specific antigen (A). Splenic T cells were also cultured with immorbilized anti-CD3 $\varepsilon$ monoclonal antibody in the presence of various concentrations of DSCG for $48 \mathrm{~h}$ (B). These cells were pulsed with $1.0 \mu \mathrm{Ci}{ }^{3} \mathrm{H}$-thymidine for the last $8 \mathrm{~h}$ of culture. The results were expressed as the mean $\pm \mathrm{SD}$ of five individual mice. NC: non-stimulated control. ${ }^{*} P<0.05$, significantly different as compared with no agent. 

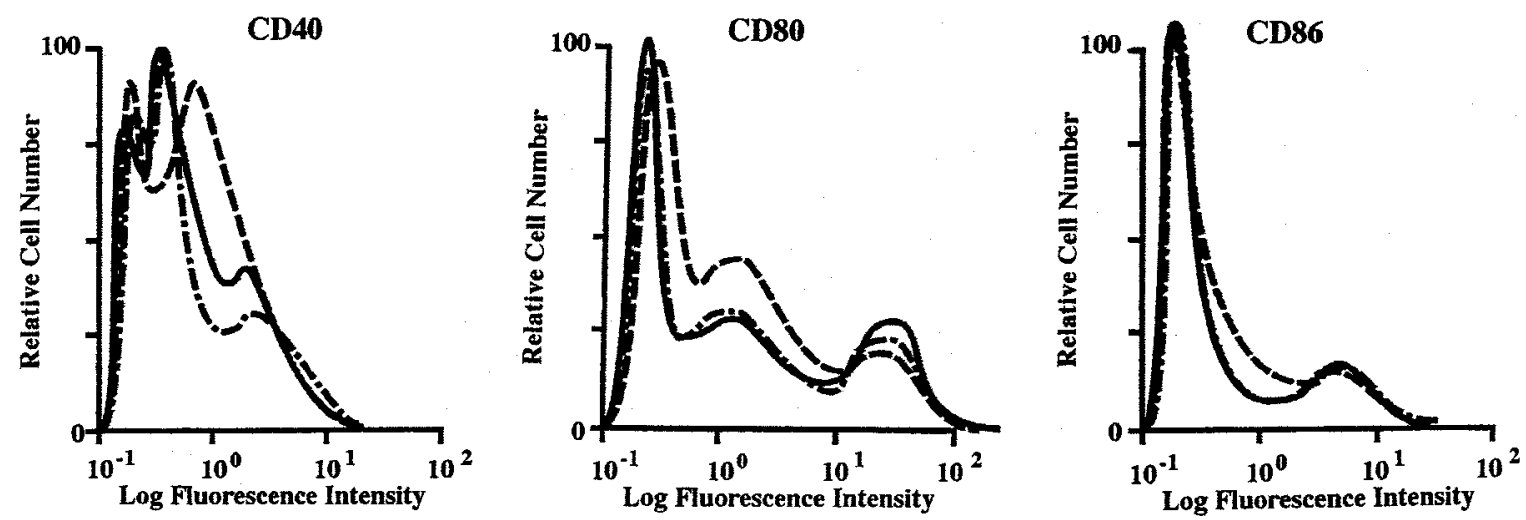

FIG. 4. Influence of disodium cromoglycate (DSCG) on co-stimulatory molecule expression on spleen cells induced by antigenic stimulation. Spleen cells $\left(1 \times 10^{6}\right.$ cells $\left./ \mathrm{ml}\right)$ prepared from five individual mice 10 days after immunization were cultured with or without $2 \times 10^{-4} \mathrm{M}$ of DSCG for $24 \mathrm{~h}$. The expression was analyzed by flow cytometer: $(-)$ cultured without antigen; $(--$ $--)$ cultured with antigen; $(-\cdot-\cdot)$ cultured with antigen and DSCG.

such as sneezing, bronchospasm and hives are believed to be largely the results of mediator release from mast cells and basophils, ${ }^{2,3}$ whereas chronic symptoms, the result of allergic inflammation, can be explained on the basis of eosinophil-mediated tissue damage. ${ }^{2,3,16}$ Based on these established ideas, the treatment of allergic diseases still focuses on the inhibition of mediator release or on blocking the binding of soluble mediators to their receptors. However, additional evidence clearly shows that $\mathrm{T}$ cells play a central role in the driving and maintenance of all these processes by elaboration of several types of cytokines. ${ }^{2,3,16,17}$ There is now also circumstantial evidence that the $\mathrm{CD} 28 / \mathrm{B} 7$ co-stimulatory is critical in T cell activation, proliferation and cytokine production. ${ }^{4-7,18}$ Yet the action of antiallergic agents on the co-stimulatory pathway is poorly understood. To examine the influence of antiallergic agents in the co-stimulatory pathway, it was first tested on the response of lymphocytes to in vitro antigenic stimulation by examining DNA synthetic activity. The present results (Figs $1 \mathrm{~A}$ and $3 \mathrm{~A}$ ) clearly show the inhibitory effect of EP and DSCG on DNA synthetic activity (proliferation) of sensitized spleen cells in response to in vitro stimulation with specific antigen. However, EP and DSCG could not inhibit DNA synthe tic activity of sensitized splenic $\mathrm{T}$ cells by anti-CD3 stimulation (Figs $1 \mathrm{~B}$ and $3 \mathrm{~B}$ ), suggesting that inhibition of the prolife rative responses of sensitized spleen cells by specific antigen is not due to cytotoxic action of the agents to splenic T cells. It is reported that anti-allergic agents did not interfere with the ability of APC to process antigens. ${ }^{19}$ The present results, therefore, may suggest that EP and DSCG inhibit proliferation of sensitized spleen cells induced by antigenic stimulation through the suppression of signal transmission required for DNA synthesis.

$\mathrm{T}$ and $\mathrm{B}$ cells play a critical role in the pathogenesis of allergic diseases. Activation of resting lymphocytes requires the engagement of the $\mathrm{T}$ cell receptor $w$ ith a
peptide/MHC as well as the engagement of appropriate co-stimulatory molecules. ${ }^{4-7}$ In particular, signals through the CD28/CTLA-4 co-stimulatory pathway are essential for primary activation of antigen specific T cells. ${ }^{20}$ It is reported that CTLA-4 immunoglobuline fusion protein (CTLA-4Ig), a blocker of CD28/B7 co-stimulation, could block allergeninduced proliferation and cytokine production of peripheral blood mononuclear cells from atopic donors, when the cells were cultured in vitro in the presence of CTLA- $4 \mathrm{Ig} .{ }^{18}$ In addition to the CD28/ CTLA-4 co-stimulatory signals, CD40 ligand (CD40L) was also reported to play an important role in the interaction between helper T cells and APC. ${ }^{21,22}$ The CD40L-CD40 interaction can upregulate the expression of B7 molecules on APC, which are essential for helper $\mathrm{T}$ cell activation, and enhances $\mathrm{T}$ cell proliferative responses. ${ }^{23,24}$ Therefore, we examined whether EP and DSCG suppress the expression of costimulatory molecules, CD40, CD80 and CD86, on sensitized B lymphocytes, induced by in vitro stimulation with specific antigen and resulted in inhibition of in vitro $\mathrm{T}$ cell proliferative responses. The present results clearly show that EP and DSCG could suppress the expression of co-stimulatory molecules, CD40 and CD80 but not CD86, on sensitized B cells which were enhanced by in vitro stimulation with antigen (Figs. 2 and 4). Prophylactic treatment of the patients with anti-allergic agents is recognized to prevent the development of the diseases by inhibition of $\operatorname{IgE}$ hyper-production, ${ }^{9,25}$ but the mechanisms are not well defined. Induction of $\mathrm{IgE}$ synthesis from B cells requires two distinct signals. The first signal is delivered by IL- 4 and the second is provided by T-B cell contact through the ligation of $\mathrm{CD} 40$ and CD40L. ${ }^{9,10}$ Together with the present results, it may be speculated that anti-allergic agents exerted inhibitory effects on the development of the diseases through the suppression of CD40 expression, when agents were administered prophylactically. 
Recent reports have examined the co-stimulatory dependence of allergen-specific human $\mathrm{T}$ cells, and the role of these CD28 and CD80 in animal models of allergic inflammation. De Boer et al. showed that CD80 could act as a co-stimulator molecule for Th2 type cytokine, IL-4 and IL-5, productions from human peripheral blood $\mathrm{T}$ cells activated by $\mathrm{mAb}$ directed at T cell receptor. ${ }^{26}$ It is also reported that CD80 blockade prevents antigen specific proliferative responses of $\mathrm{T}$ cells from atopic dermatitis against Dermatophagoides farinae. ${ }^{27}$ In murine models for inflammatory diseases, blockade of CD80 is reported to ameliorate the diseases. ${ }^{28}$ With regard to the influence of CD80 on effector cell (e.g. eosinophil) functions, Tsuyuki et al. showed that intranasal administration of anti-CD80 $\mathrm{mAb}$ inhibited eosinophil accumulation in lungs and airway tracts, but was less effective in inhibiting peripheral blood eosinophilia induced by aerosol provocation of allergen. ${ }^{29} \mathrm{CD} 80$ blockade was also reported to be able to prevent eosinophil influx into lungs and airway tracts when the mice were injected with anti-CD80 $\mathrm{mAb}$ during the aerosol challenge. ${ }^{30}$ These suppressive effects of CD80 may be owing to its inhibitory action on adhesion molecule expressions, since CD80 blockade is reported to prevent acquisition by lymphocytes including eosinophils of the adhesion molecules involved in recirculation through tissue, and upregulation of their ligands such as ICAM-1 on endothelium. ${ }^{31}$ Judging from these reports, the present results showing the suppressive effect of anti-allergic agents on CD80, but not CD86, expression suggest that anti-allergic agents, especially EP and DSCG, are effective in the prevention of allergic inflammatory responses in lungs and airway tracts.

Pharmacological studies revealed that EP and DSCG prevent calcium cation influx into immune cells, ${ }^{14,32}$ resulting in reduced permeability of cell membrane and inhibition of expression of proteins synthesized in the cytosol. It is also reported that anti-allergic agents including EP and DSCG increase intracellular cyclic adenosine monophosphate (cAMP) level by inhibiting adenylate cyclase activity. ${ }^{14,33}$ Elevation of intracellular cAMP level elaborates an important down-regulatory signal in the release of proteins synthesized in the cytosol. ${ }^{34,35}$ From these reports, it is possible that EP and DSCG cause prevention of the accumulation of calcium cation in the cytosol and enhance intracellular cAMP level resulting in inhibition of $\mathrm{CD}$ molecule expressions. Although the present data add novel information about the beneficial effects of antiallergic agents on the diseases, the precise mechanism(s) by which the agents inhibit co-stimulatory molecule expressions is not yet fully understood. Further experiments are needed to clarify this point.

\section{References}

1. Snapper JR. Inflammation and airway function: The asthma syndrome. Am Rev Respir Dis 1990: 141:531-3.

2. Kay AB. T lymphocytes and the ir products in atopic allergy and asthma. Int Arch Allergy Appl Im munol 1991:94:189-93.

3. Corrigan CJ, Kay AB. T cells and eosinophils in the pathogenesis of asthma. Im munol Today 1992:13:501-6.

4. Mueller DL, Jenkins MK, Schwartz RH. Clonal expansion versus functional clonal inactivation: a co-stimulatory signalling pathway determines the out come of T cell antigen receptor occupancy. Annu Rev Im munol 1989:7:445-80.

5. Robinson DS. T cell costimulation: a potential therapeutic target in asthma? Clin Exp Im munol 1998:28:788-90.

6. Schwartz RH. Costimulation of Tlymphocytes: The role of CD28, CTLA-4 and $\mathrm{B} 7 / \mathrm{BB} 1$ in interleukin-2 production and immunotherapy. Cell 1992:71:1065-8.

7. Lenschow DJ, Walunas TL, Bluestone JA. CD28/B7 system of T cell costimulation. Annu Rev Im munol 1996:14:233-58.

8. Schwartz RH. Models of T cell anergy: is there a common molecular mechanism? J Exp Med 1996:184:1-8.

9. Loh RKS, Jabara HH, Geha RS. Disodium cromoglycate inhibits $S v$ to $S \varepsilon$ deletional switch recombination and $\operatorname{IgE}$ synthesis in human B cells. $J$ Exp Med 1994:180:663-71.

10. Worm M, Henz BM. Melecular regulation of human IgE synthesis. J Mol Med 1997:75:440-7

11. Podleski WK, Panaszek BA, Schmidt JL, Burrs RB. Inhibition of eosinophil degranulation by in a patients with milk allergy, manifested as bronchial asthma-an electron microscopic study. Agents Actions 1984:5:177-81.

12. Tasaka K, Mio M, Okamoto M. Intracellular calcium release induced by histamine release and its inhibitory by some antiallergic drugs. Ann Allergy 1986:56:464-9.

13. Yanagihara Y, Kasai H, Kawashima T, Shida T. Immunopharmacological studies on TBX, a new antiallergic drug. Jpn J Pharmacol 1988:48:91-6.

14. Tasaka K, Akagi M, Izushi K, Aoki I. Antiallergic effect of epinastine: the elucidation of the mechanism. Pharmacometrics 1990:39:365-73.

15. Morimoto $\mathrm{C}$, Torimoto $\mathrm{Y}$, Levinson G, et al. $1 \mathrm{~F} 7$, a novel cell surface molecule involved in helper function of CD4 cells. J Immunol 1989: 143:3430-9.

16. Kay AB. Role of T cells in asthma. Allergy Int 1997:46:73-82.

17. Frew AJ. Cytokines, chemokines, T cells and allergy. Clin Exp Allergy 1996:26:2-4.

18. Van Neerven RJJ, Van De Polo MM, Van Der Zee JS, et al. Requirement of CD28-CD86 costimulation for allergen-specific $\mathrm{T}$ cell proliferation and cytokine expression. Clin Exp Allergy 1998:28:808-16.

19. Riese RJ, Mitchell RN, Villadangos JA, et al. Cathepsin S activity regulates antigen presentation and immunity. J Clin Invest 1998:101: 2351-63.

20. Azuma M, Cayabyab M, Buck D, Phillips JH, Lanier LL. CD28 interaction with B7 costimulates primary allogeneic proliferative responses and cytotoxicity mediated by small, resting T lymphocytes. I Exp Med 1992: 175:353-60.

21. Blazar BR, Taylor PA, Panoskaltsis-Mortari A, et al. Blocking of CD40 ligand-CD40 interaction impairs CD4 + T cell-mediated alloreactivity by inhibiting mature donor $\mathrm{T}$ cell expansion and function after bone marrow transplantation. I Im munol 1997:158:29-39.

22. Saito K, Sakurai J, Ohata J, et al. Involvement of CD40 ligand-CD40 and CTLA4-B7 pathways in murine acute graft-versus-host disease induced by allogeneic T cells lacking CD28. J Im munol 1998: 160:4225-31.

23. Cayabyab M, Phillips JH, Lanier LL. CD40 preferentially co-stimulates activation of CD4+ T lymphocytes. J Im munol 1994:152:1523-31.

24. Roy M, Aruffo A, Ledbetter J, et al. Studies on interdependence of gp39 and B7 expression and function during antigenspecific immune responses. Eur J Immunol 1995:25:596-603.

25. Church M, Polosa R, Rimmer S. Cromolyn sodium and nedocromil sodium. Mast cell stabilizers, neuromodulators, or anti-inflammatory drugs? In: Kaliner MA, Barnes PJ, Persson CGA, eds Asthma. Its Pathology and Treatment. New York: Marcel Dekker, 1991, pp. 561-93.

26. De Boer M, Kasran A, Kwekkeboom J, et al. Ligation of B7 with CD28/ CTLA4 on $\mathrm{T}$ cells results in CD40 ligand expression, interleukin 4 secretion, and efficient help for antibody production by B cells. Eur $J$ Immunol 1993; 23:3120-3125.

27. Kawamura MS, Aiba S, Tagami H. The importance of CD54 and CD86 costimulation in T cells stimulated Candida albicans and Dermatophagoides farinae antigens in patients with atopic dermatitis. Arch Dermatol Res 1998; 290: 603-609.

28. Kuchroo VK, Das MP, Brown JA, et al. B7-1 and B7-2 costimulatory molecules activate differentially the Th1/Th2 developmental pathways: application to autoimmune disease the rapy. Cell 1995; 80: 707-718.

29. Tsuyuki S, Tsuyuki J, Einsle K, Kopf M, Coyle AJ. Costimulation through B7-2 (CD86) is required for the induction of a lung mucosal Thelper cell 2 (TH2) immune response and altered airway responsiveness.J Exp Med 1997; 185: $1671-1679$. 
30. Harris N, Peach R, Naemura J, et al. CD80 costimulation is essential for the induction of airway eosinophilia J Exp Med 1997; 185: 177-182.

31. Nakajima H, Sano H, Nishimura S, Yoshida S, Iw amoto I. Role of vascular adhesion molecule $1 /$ very late activation antigen 4 and intercellular adhesion molecule 1/lymphocyte function-associated antigen 1 interactions in antigen-induced eosinophil and $\mathrm{T}$ cell recruitment into the tissue. J Exp Med 1994; 179: 1145-1154.

32. Spataro AC, Bosmann HB. Mechanism of action of disodium cromoglycate-mast cell calcium ion influx after a histamin-releasing stimulus. Biochem Pharmacol 1976:25:505-10.

33. Akagi M, Mio M, Tasaka K, Kinima S. Histamine release inhibition and prevention of the decrease in membrane fluidity induced by certain anti- allergic agents. Agents Actions 1983:12:149-53.

34. Endres S, Fulle HJ, Sinha B, et al. Cyclic nucleotides differentially regulate the synthesis of tumour necrosis factor- $\alpha$ and interleukin-1 $\beta$ by human mononuclear cell. Im munology 1991:72:56-60.

35. Shimozato T, Iwata M, Kawada H, Tamura N. Human immunoglobulin preparation for intravenous use induces elevation of cellular cyclic adenosine 3'5'-monophos phate levels, resulting in suppression of tumor necrosis factor alpha and interleukin 1 production. Im munology 1991:72:497-501.

\section{Accepted 2 May 2000}




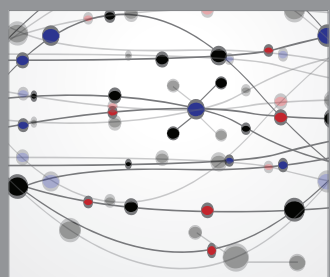

The Scientific World Journal
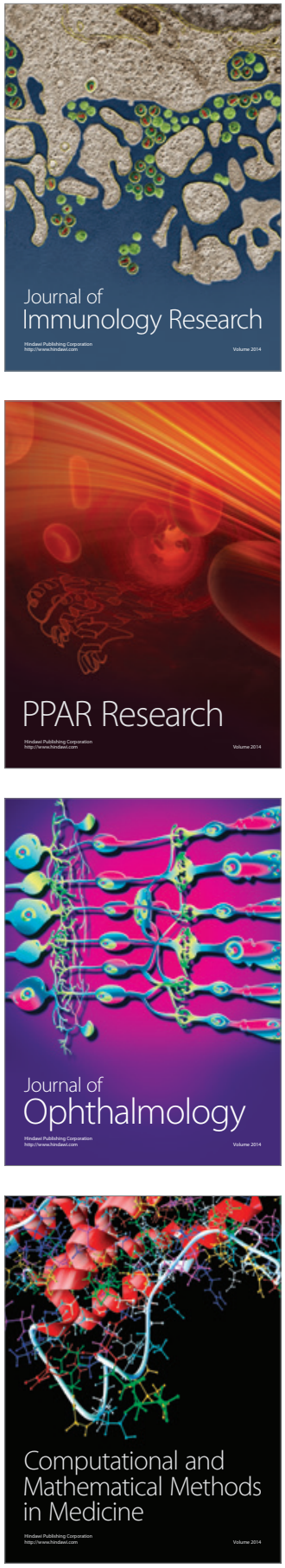

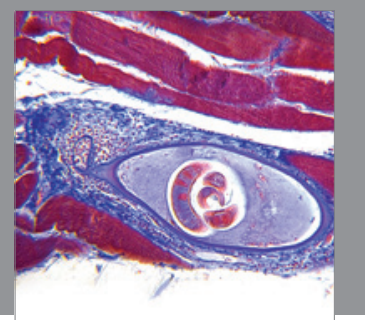

Gastroenterology

Research and Practice
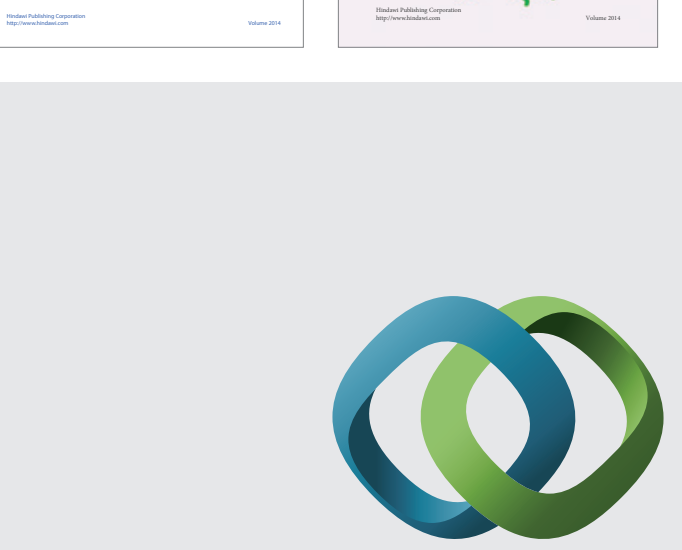

\section{Hindawi}

Submit your manuscripts at

http://www.hindawi.com
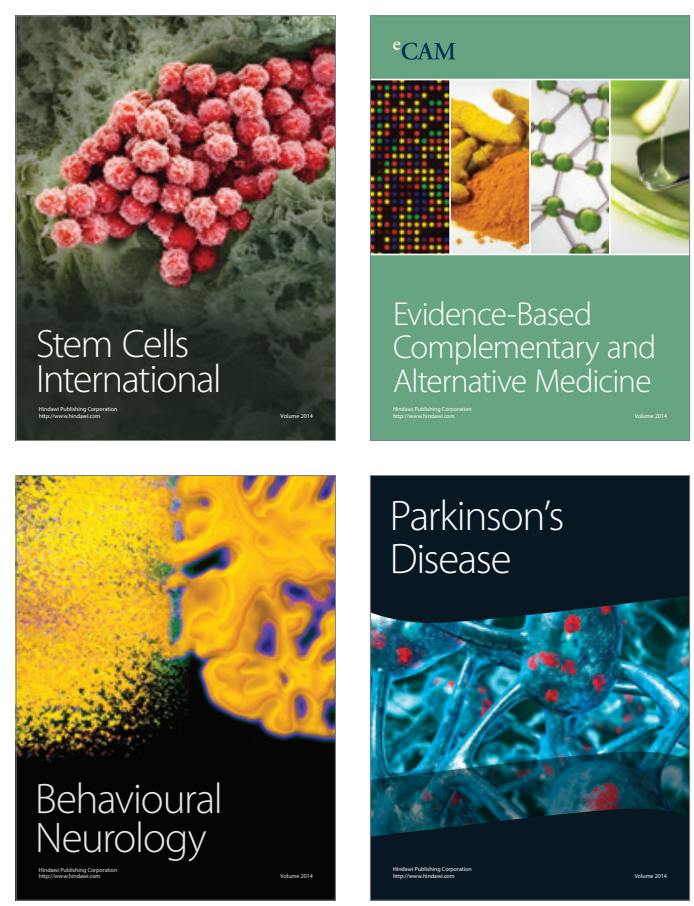

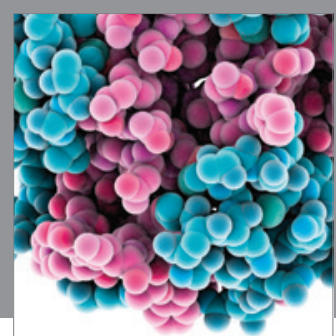

Journal of
Diabetes Research

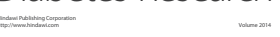

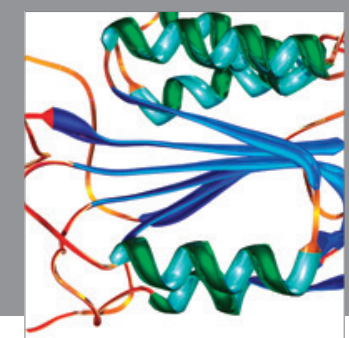

Disease Markers
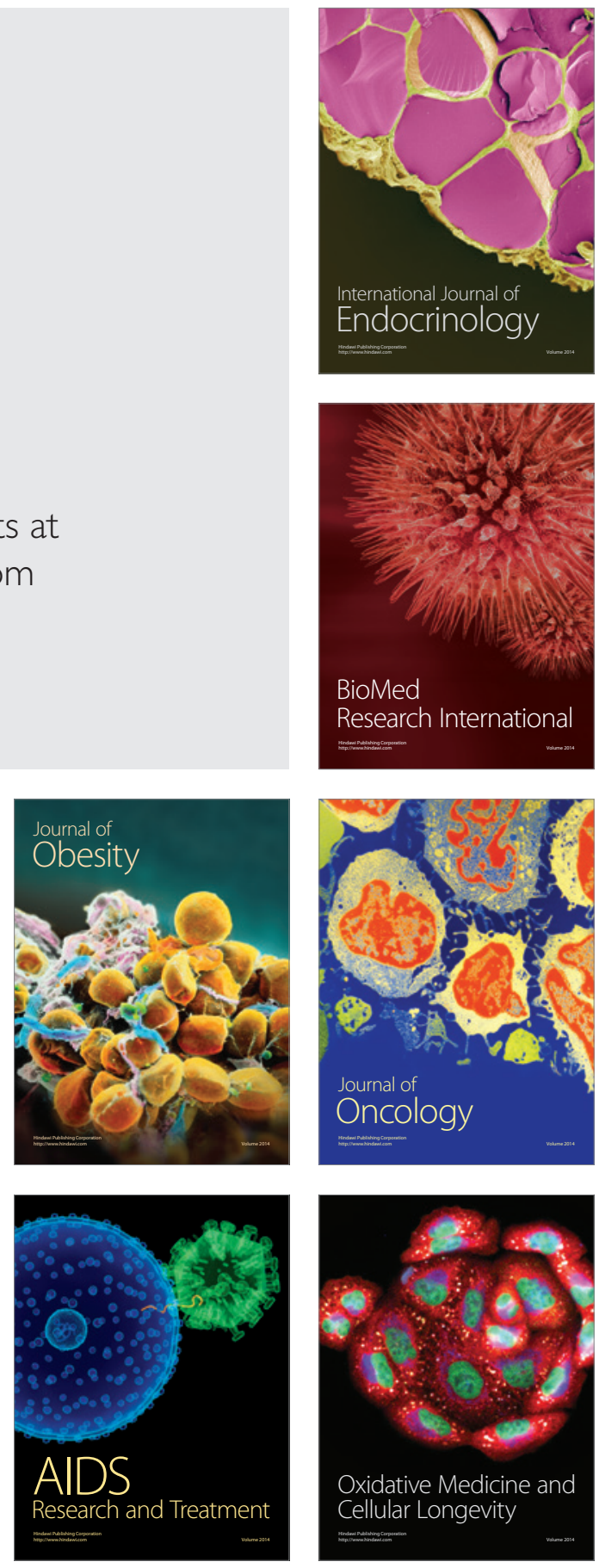